\title{
CHARAKTER PRAWNY TERMINÓW W KODEKSIE SPÓŁEK HANDLOWYCH
}

\section{Wprowadzenie}

Kodeks spółek handlowych posługuje się wieloma terminami, rozumianymi zgodnie z przepisami prawa cywilnego zarówno jako okres czasu, jak i pewna chwi$1 \mathrm{a}^{2}$. W związku z różnorodnością występujących terminów można dokonać ich klasyfikacji, w oparciu o zróżnicowane kryteria. Korzystając z podziału uwzględniającego jako zasadnicze kryterium źródło regulacji, terminy ksh można podzielić na: ustawowe (np.: art. $6 \S 1$, art. $57 \S 2$, art. $198 \S 4$ ), sądowe (np.: art. 165, art. 172, art. 327) oraz umowne (np.: art. $62 \S 2$ in fine, art. $330 \S 1$, art. 337 §). Ponadto, przy zastosowaniu kryterium podmiotowego można wyróżnić terminy odnoszące się do spółki: jawnej (np.: art. 57 § 2), partnerskiej (np.: art. 98 §), komandytowej (na podstawie art. 103 te odnoszące się do spółki jawnej), komandytowo-akcyjnej (np.: art. $137 \S 4$ ), z ograniczoną odpowiedzialnością (np.: art. 169, art. $193 \S 3$ ), akcyjnej (np.: art. 325, art. $358 \S 3$, art. $402 \S 1$ ) czy też regulujących zagadnienia związane z przekształceniami spółek (np.: art. 500 §, art. $504 \S 1$, art. $51618 \S 3$ ). Biorąc zaś pod uwagę sposób regulacji wyrażony w przepisach ustawy, mogą być one terminami bezpośrednio w niej określonymi (np.: art. $6 \S 1$, art. $17 \S 2$ ) lub terminami znajdującymi się w innych aktach prawnych, do których ustawa odsyła (np. art. 299). Powyższe klasyfikacje są jedynie przykładami możliwych podziałów terminów występujących w ustawie.

Terminy, o których mowa w ksh. można także przypisać do jednej z dwóch kategorii terminów przedawnienia lub zawitych (prekluzyjnych). Celem niniejszego opracowania jest przede wszystkim ogólne określenie charakteru prawnego wspo-

M.J. Skrodzka opracowanie pierwszej części artykułu (punkty 1-3), K. Skrodzki drugiej części (punkty 4-5).

Z. Radwański, Treść czynności prawnej, (w:) System Prawa Prywatnego, Prawo cywilne - część ogólna, T. 2, red. Z. Radwański, Wyd. 2, Warszawa 2008, s. 277. 
mnianych terminów przedawnienia oraz zawitych, jak również dokonanie ich rozróżnienia na konkretnych przykładach.

\section{Terminy przedawnienia roszczeń a terminy zawite}

Doktryna nie jest zgodna co do jednoznacznego określenia poszczególnych cech charakterystycznych, zmierzających do rozróżnienia terminów przedawnienia i zawitych $^{3}$. Coraz częściej wskazywana jest płynność granicy oddzielającej od siebie przedmiotowe terminy ${ }^{4}$. Niemniej jednak, w oparciu o pięć zasadniczych kryteriów, tj.: przedmiot terminu; skutek jego upływu; wystapienie skutku upływu terminu; ocenę nadużycia prawa podmiotowego przez osobę, przeciwko której przysługuje roszczenie; oraz zawieszenie czy przerwanie biegu terminu, można dokonać rozróżnienia terminów przedawnienia roszczeń od terminów prekluzyjnych.

Pierwszym kryterium pozwalającym na przyporządkowanie terminu ujętego w ksh. do określonej kategorii jest przedmiot podlegający przedawnieniu bądź prekluzji. Terminem przedawnienia są bowiem objęte, co do zasady, roszczenia majątkowe, zaś terminem zawitym uprawnienia kształtujące, których wykonanie należy do zainteresowanego podmiotu (zawity termin pozasądowy) i uprawnienia do dochodzenia ukształtowania lub ustalenia stosunków prawnych przez sąd (zawity termin sądowy) ${ }^{5}$. Zastosowanie kolejnej przesłanki - skutku upływu terminu, powoduje, że w przypadku terminu przedawnienia zobowiązanie cywilne ulega przekształceniu w zobowiązanie niezupełne. Zobowiązanie zatem istnieje nadal, ale nie jest możliwa jego przymusowa egzekucja, ze względu na fakt, że dłużnik wraz z upływem terminu zwolniony jest z odpowiedzialności wynikającej z istniejącego obowiązku6 ${ }^{6}$ W przypadku prekluzji pozasądowej upływ terminu skutkuje wygaśnięciem praw, w odniesieniu do prekluzji sądowej zaś wygaśnięciem uprawnienia, które było terminem tym ograniczone, a co się z tym wiąże niemożnością realizacji uprawnienia na drodze sądowej ${ }^{7}$.

Trzecia cecha, która wpływa na charakter prawny terminu, odnosi się do określenia podmiotu decydującego o wystapieniu skutku upływu terminu. W przypadku przedawnienia ustawodawca pozostawia decyzję stronie zobowiązanej do uczynienia zadość roszczeniu w chwili upływu terminu ${ }^{8}$. Po wyraźnym (wyrażonym przed

3 B. Kordasiewicz, Problematyka dawności, (w:) System..., op. cit., s. 565 i nast.

4 M. Pyziak-Szafnicka, Komentarz do art. 117 kodeksu cywilnego, (w:) Kodeks cywilny. Część ogólna. Komentarz,

B. Giesen, W.J. Katner, P. Księżak, B. Lewaszkiewicz-Petrykowska, R. Majda, E. Michniewicz-Broda, T. Pajor, U. Promińska, M. Pyziak-Szafnicka, W. Robaczyński, M. Serwach, Z. Świderski, M. Wojewoda, Warszawa 2009.

6 B. Kordasiewicz, Problematyka dawności, (w:) System..., op. cit., s. 565 i nast.

$7 \quad$ Ibidem

8 M. Pyziak-Szafnicka, Komentarz do art. 117 kodeksu cywilnego, (w:) Kodeks..., op. cit. 
sądem) zarzucie przedawnienia sformułowanym przez uprawnionego, sąd bada, biorąc pod uwagę wszystkie przesłanki faktyczne i prawne, czy przedawnienie rzeczywiście nastąpiło. Dopiero po dokonaniu przedmiotowej oceny i uznaniu zaistnienia przesłanek przedawnienia sąd oddala powództwo. W odniesieniu do prekluzji ustawodawca nie przyznaje stronom uprawnienia do podniesienia zarzutu prekluzji. Powstaje ona niezależnie od woli stron, ex lege, a sąd uwzględnia upływ czasu w przypadku terminu zawitego z urzędu, bez względu na świadomość stron w tym zakresie ${ }^{9}$. W związku z tym sąd oddala powództwo o ukształtowanie albo ustalenie stosunku prawnego z urzędu, a w sytuacji sporu co do następstw określonych zachowań strony za podstawę swego orzeczenia przyjmuje bezskuteczność tych czynności, jako dokonanych przez nieuprawnionego ${ }^{10}$.

Przypisanie kryterium nadużycia prawa podmiotowego przez osobę, przeciwko której przysługuje roszczenie, tylko jednej z dwóch kategorii terminów nie jest jednoznaczne. Ogólne ujęcie tej problematyki pozwala na sformułowanie twierdzenia, że możliwość oceny roszczenia na podstawie przepisu art. $5 \mathrm{kc}$. jest możliwa, co do zasady, wyłącznie w przypadku terminów przedawnienia, wynika bowiem zarówno z konstrukcji nadużycia prawa podmiotowego, jak i mechanizmu działania preklu$\mathrm{zji}^{11}$. Podobnie rzecz ma się z możliwością zastosowania instytucji zawieszenia czy przerwania biegu terminu, które - co do zasady - odnoszą się wyłącznie do terminów przedawnienia.

Na podstawie przyjętego rozróżnienia terminami przedawnienia występującymi w ksh., są te związane m.in. z: wyrównawczą odpowiedzialnością wspólnika spółki kapitałowej za wadliwy wkład niepieniężny (art. 14 §), odpowiedzialnością wspólnika spółki z o.o. za przeszacowanie wkładu niepieniężnego wniesionego do spółki (art. 175 § 1) czy odpowiedzialności zarządu za zobowiązania spółki z o.o. w przypadku, gdy egzekucja z jej majątku okaże się bezskuteczna (art. 299 § 1).

Za terminy zawite zaś uznaje się m.in. termin:

- na wniesienie powództwa o stwierdzenie nieważności uchwały zgromadzenia wspólników spółki z o.o. lub walnego zgromadzenia akcjonariuszy publicznej spółki akcyjnej (art. 252 §, art. 425 §),

- powództwa o uchylenie uchwały zgromadzenia wspólników spółki z o.o. lub walnego zgromadzenia spółki akcyjnej (art. 251, art. 424 § 1).

- wezwania wspólników spółki przekształcanej do złożenia oświadczeń o uczestnictwie w spółce przekształconej (art. 564 § 1), 
- czy odpowiedzialności wspólników spółki osobowej przekształconej w spółkę kapitałową (art. 574).

\section{Termin przedawnienia roszczeń}

Terminy przedawnienia roszczeń, podobnie jak zawite, nie zawsze wyrażone są bezpośrednio w ustawie. Zdarza się, że ustawodawca formułuje jedynie roszczenie, precyzuje jego charakter i na tej podstawie odsyła do stosowania odpowiednich przepisów o terminach, pozostawiając do uznania judykatury bądź doktryny ewentualne wątpliwości pojawiające się na tle tak sformułowanego zapisu. Przykładem terminu przedawnienia niewskazanego wprost jest przepis art. 299 ksh., który odnosi się do problematyki odpowiedzialności członków zarządu spółki z o.o. w sytuacji, gdy egzekucja przeciwko spółce okaże się bezskuteczna. Pomimo że literalne brzmienie przepisu nie wskazuje konkretnego terminu, ustanawia roszczenie wierzyciela spółki przeciwko członkom zarządu oraz sposób zwolnienia się członków zarząa od zwolnienia się z roszczenia. W judykaturze i piśmiennictwie dominują dwa odmienne stanowiska ${ }^{12}$ w kwestii określenia charakteru odpowiedzialności członków zarządu spółki z o.o. w trybie art. 299. Najnowsze orzecznictwo i część doktryny przyjmuje, że ma owa odpowiedzialność charakter odszkodowawczy, wiąże się bowiem z dopuszczeniem do obniżenia potencjału majątkowego spółki, powodującego niemożność wyegzekwowania jej zobowiązań ${ }^{13}$. Pogląd ten podzielają autorzy artykułu. Tak określone roszczenie powoduje pytanie o termin jego przedawnienia. Ze względu na charakter odszkodowawczy i wystapienie szkody podlega ono przedawnieniu nie na zasadach ogólnych (art. $118 \mathrm{kc}$.), lecz na podstawie przepisów o naprawieniu szkody wyrządzonej czynem niedozwolonym (art. $442 \S$ $1 \mathrm{kc}$. $)^{14}$. Jako podstawę terminu przedawnienia dla pozwanych członków zarządu wskazuje się również termin zawarty w przepisie art. $125 \S 1 \mathrm{kc} .{ }^{15}$ Kolejną kwestią niedającą się jednoznacznie zinterpretować, a związaną z przedmiotowym trzyletnim terminem przedawnienia, jest określenie rozpoczęcia jego biegu. Sąd Naj-

12 Poglądy opowiadające się za charakterem gwarancyjnym odpowiedzialności członków zarządu ponoszonej w trybie art. 299 ksh., zob. m.in.: A. Szajkowski, (w:) Kodeks handlowy. Komentarz, S. Sołtysiński, A. Szajkowski, J. Szwaja, T. I, Warszawa 1997, s. 1190-1191; wyrok Sądu Najwyższego z dnia 6 czerwca 1997 r., III CKN 65/97, OSNC 1997, nr 11, poz. 18; wyrok Sadu Najwyższego z dnia 17 lipca 1997 r., III CKN 126/97, OSP 1998, z. 3, poz. 62; wyrok Sądu Najwyższego z dnia 11 października 2000 r., III CKN 252/00, Lex nr 51887. Poglądy opowiadające się za charakterem odszkodowawczym odpowiedzialności członków zarządu ponoszonej na podstawie art. 299 ksh., zob. m.in.: P. Jamorski, Odpowiedzialność członków zarządu spółki z o.o. na podstawie art. 299 ksh., „Monitor Prawniczy” 2002, nr 14, s.; wyrok Sądu Najwyższego z dnia 2 października 2007 r., II CSK 301/07, Lex nr 332957; uchwała Sądu Najwyższego z dnia 7 listopada 2008 r., III CZP 72/08, OSNC 2009, nr 2, poz. 20.

13 A. Michór, Przedawnienie roszczeń przeciwko członkom zarządu spółki z o.o. dochodzonych na podstawie art. 299 KSH, „Rejent” 2008, nr 4, s. 55 i nast.

14 Postanowienie Sądu Najwyższego z dnia 8 grudnia 2008 r., III CZP 112/08, Lex nr 490503.

15 Tak: A. Michór, Przedawnienie..., op. cit., s. 55 i nast. 
wyższy, próbując rozstrzygnąć ten problem, przyjmuje różne koncepcje. Stwierdza m.in., że termin ten powinien być liczony od dnia:

- dowiedzenia się przez powoda o wydaniu postanowienia o umorzeniu postępowania upadłościowego, o ile z treści tego postanowienia wynika oczywisty brak majątku spółki na zaspokojenie kosztów postępowania upadłościowego. $\mathrm{Z}$ tym bowiem dniem powód dowiedział się o szkodzie i o osobie obowiązanej do jej naprawienia ${ }^{16}$;

- uzyskania przez wierzyciela świadomości, że wyegzekwowanie długu od spółki jest niemożliwe ${ }^{17}$.

Mimo takiego określenia rozpoczęcia biegu trzyletniego terminu mającego zastosowanie w przypadku roszczeń w trybie art. 299 , kwestia ta nadal pozostaje nierozstrzygnięta.

Podobny problem z określeniem charakteru terminu oraz początku jego biegu występuje na tle regulacji przepisów art. $14 \S 2$ oraz art. $175 \S 1$. Przepis art. $14 \S 2$ odnosi się do wyrównawczej odpowiedzialności wspólnika spółki kapitałowej za wadliwy wkład niepieniężny, zaś przepis art. $175 \S 1$ reguluje kwestię odpowiedzialności wspólnika spółki z o.o. za tzw. przeszacowanie wkładu niepieniężnego wniesionego do spółki. Pomimo zbliżonego ujęcia, przepis odnoszący się do wadliwego określenia wartości wkładu ma szerszy zakres podmiotowy (odnosi się bowiem zarówno do wspólnika, który wniósł przeszacowany wkład do spółki, jak i do członka zarządu, który mu na to pozwolił), lecz węższy zakres przedmiotowy, sprowadzający się wyłącznie do świadczenia pieniężnego ${ }^{18}$. Zarówno przepis art. $14 \S 2$ oraz art. $175 \S 1$, regulując uprawnienia spółki w stosunku do wspólnika, nie wskazują terminów do ich dochodzenia i nie określają tym samym, czy są to terminy przedawnienia czy zawite. Aby rozstrzygnąć tę kwestię, należy określić charakter wskazanych roszczeń. Jak słusznie wskazuje A. Szumański, uprawnienia te mają charakter roszczenia, w związku z tym stosuje się do nich terminy przedawnienia. Zarówno odpowiedzialność wspólnika za wadliwy wkład niepieniężny, jak i przeszacowanie wkładu stanowią autonomiczną instytucję prawa spółek, zbliżoną do odpowiedzialności za wady fizyczne i prawne rzeczy sprzedanej lub oddanej w najem (art. 556576 i art. $664 \mathrm{kc}$. $)^{19}$. Regulacja zawarta w przepisie art. $2 \S 2 \mathrm{ksh}$. pozwala na odpowiednie stosowanie przepisów o odpowiedzialności za wady fizyczne i prawne rzeczy sprzedanej do wadliwych lub wadliwe określonych wkładów ${ }^{20}$. Możliwość odpowiedniego stosowania wspomnianych przepisów budzi jednak wątpliwość co

16 Wyrok Sądu Najwyższego z dnia 2 października 2007 r., II CSK 301/07, Lex nr 332957.

17 Wyrok Sądu Najwyższego z dnia 31 stycznia 2007 r., II CSK 417/06, „Monitor Prawniczy” 2007, nr 5, s. 229.

18 A. Szumański, Komentarz do art. 14, (w:) Kodeks spółek handlowych. Komentarz do artykułów 1-150, S. Sołtysiński, A. Szajkowski, A. Szumański, J. Szwaja, T. 1, Wyd. 2, Warszawa 2006, s. 246.

19 Ibidem

20 Ibidem 
do wskazania początku biegu terminu przedawnienia. W sytuacji bowiem zastosowania ogólnych terminy przedawnienia roszczeń na podstawie art. $118 \mathrm{kc}$., bieg terminu liczony będzie od dnia wniesienia wkładu. W sytuacji odpowiedniego zastosowania art. $576 \mathrm{kc}$. odnoszącego się do wady prawnej wkładu, termin ten winien biec od momentu, kiedy spółka dowiedziała się o istnieniu wady.

Inną kwestią sporną jest określenie długości terminu przedawnienia roszczeń na podstawie przepisów art. $14 \S 2$ oraz art. $175 \S 1$. Pomimo odrzucenia możliwości analogicznego zastosowania w tym zakresie przepisów kc. o rękojmi, samo określenie długości terminu na postawie art. $118 \mathrm{kc}$. staje się sporne. Stanowisko doktryny wskazuje na zastosowanie trzyletniego terminu przedawnienia, ze względu na fakt, że roszczenie związane jest z prowadzeniem działalności gospodarczej ${ }^{21}$. Mimo to, z powodu braku bezpośredniej regulacji, uwzględnia się pogląd $\mathrm{d}^{22}$, zgodnie z którym do spółek nieprowadzących działalności gospodarczej oraz wspólników spółki, których celem jest jedynie lokata kapitału, zastosowanie znajdzie termin dziesięcioletni wskazany w art. $118 \mathrm{zd} .1 \mathrm{kc}$.

Zdaniem autorów niniejszego opracowania, odpowiednie stosowanie terminów rękojmi z kc. wyłącznie do określenia biegu terminu przedawnienia jest nietrafne. Określenie początku biegu terminu przedawnienia na podstawie przepisów o rękojmi, zaś długości terminu na zasadach ogólnych, wprowadziłoby pewien chaos. W związku z tym należy podzielić pogląd, iż zarówno do określenia początku biegu terminu przedawnienia roszczeń ukształtowanych na podstawie art. $14 \S 2 \mathrm{i}$ art. 175 $\S 1$, jak i długości terminu przedawnienia należy stosować ogólny - trzyletni termin przedawnienia roszczeń wynikający z przepisu art. $118 \mathrm{kc}$.

\section{Termin zawity}

Jednym $\mathrm{z}$ terminów ujętych $\mathrm{w}$ ksh. i niewątpliwie wzbudzającym kontrowersje jest termin zawarty w przepisie art. 574 . Spory na jego tle występują mimo zgodnego zakwalifikowania go zarówno przez doktrynę, jak i judykaturę do kategorii terminów zawitych ${ }^{23}$.

Przepis ten odnosi się do odpowiedzialności wspólników spółki osobowej przekształconej w spółkę kapitałową i stanowi, że wspólnicy przekształconej spółki osobowej odpowiadają na dotychczasowych zasadach solidarnie ze spółką prze-

21 M. Goss, Odpowiedzialność wyrównawcza z tytułu przeszacowania aportu na gruncie kodeksu spółek handlowych, „Prawo Spółek” 2006, nr 11, s. 19-20.

22 Ibidem, s. 20; także: uchwała Sądu Najwyższego z dnia 29 października 2009 r., III CZP 61/09, Biul. SN 2009, nr 10, s. 10.

23 Vide.: A. Stępień, Charakter prawny terminu z art. 574 kodeksu spółek handlowych, „Prawo Spółek” 2006, nr 5 , s. 28-32; wyrok Sądu Apelacyjnego w Poznaniu z dnia 14 maja 2008 r. I ACa 319/08, Lex nr 4999179; wyrok Sądu Najwyższego z dnia 5 lutego 2009 r. I CSK 333/08, „Monitor Prawniczy” 2009, nr 6, s. 299. 
kształconą za zobowiązania spółki powstałe przed dniem przekształcenia. Okres odpowiedzialności wynosi trzy lata i jest liczony od dnia przekształcenia. Regulacja ma na celu ochronę wierzycieli przekształcanej spółki osobowej i uniemożliwienie wykorzystania natury spółki kapitałowej do naruszenia ich interesów ${ }^{24}$. W sytuacji przekształcenia spółki osobowej w kapitałową dochodzi bowiem do zmiany charakteru odpowiedzialności wspólników za zobowiązania spółki, a reżim ich odpowiedzialności zostaje zawężony, stając się mniej korzystnym dla wierzycieli byłej spółki osobowej. Przepis art. 574 wprowadza kontynuację dotychczasowej odpowiedzialności wspólników przekształconej spółki i tym samym skutecznie zapobiega nadużyciom we wskazanej sytuacji oraz ewentualnemu pokrzywdzeniu wierzycieli byłej spółki osobowej.

Słusznym jest pogląd wyrażony w orzecznictwie, że trzyletni termin kontynuacji odpowiedzialności wspólników na dotychczasowych zasadach jest terminem o specyficznym charakterze, ponieważ wyznacza okres czasu, po upływie którego wygasa odpowiedzialność wspólników spółki osobowej i brak jest możliwości jego egzekwowalności ${ }^{25}$. Ponadto trafnie wskazuje się, że przyjęte sformułowanie jest odmienne od typowych przepisów cywilnoprawnych przewidujących zawite terminy do dochodzenia prawa przed organem państwowym, jest w nim bowiem mowa o trwaniu - długości wskazanej tu odpowiedzialności, nie zaś o tym, jak długo wierzyciel może podejmować czynności zmierzające do dochodzenia czy ustalenia jego roszczenia ${ }^{26}$. Takie sformułowanie istotnie wpływa na sytuację wierzyciela dochodzącego swoich praw na jego podstawie, oznacza bowiem, że samo podjęcie czynności zmierzających do dochodzenia (ustalenia) roszczenia przed upływem trzyletniego terminu nie gwarantuje mu prawa do jego dochodzenia do czasu zakończenia wszczętej procedury. Przepis art. 574 wyraźnie stanowi, że to upływ trzyletniego terminu jest granicą osiągalności roszczenia. Moment wystąpienia z roszczeniem w ciągu tego okresu nie ma zatem żadnego wpływu na upływ terminu, nie jest bowiem możliwe, tak jak w przypadku terminów przedawnienia, powołanie się na przepisy odnoszące się do jego biegu, w tym na zawieszenie czy przerwanie jego biegu.

Trzyletni termin uznaje się za wystarczająco długi okres przejściowy na zmianę charakteru prawnego odpowiedzialności wspólników spółki przekształconej, a tym samy na dojście swoich praw przez wierzycieli spółki przekształconej. Mimo to, literalne brzmienie przepisu jest niebezpieczne w sytuacji, gdy wspólnicy spółki przekształconej, chcąc uniknąć odpowiedzialności za dotychczasowe zobowiązania spółki osobowej, skutecznie przeciągają postępowanie przed sądem, tak aby upły-

A. Szumański, Komentarz do art. 574, (w:) Kodeks spółek handlowych. Komentarz do artykułów 459-633, T. 4, S. Sołtysiński, A. Szajkowski, A. Szumański, J. Szwaja, Wyd. 2, Warszawa 2009, s. 1270. 
nął ów trzyletni termin zawity i aby ze względu na jego charakter prawny egzekucja stała się niemożliwa do wykonania. Duże prawdopodobieństwo zaistnienia opisanej sytuacji, mające na celu ewidentne pokrzywdzenie wierzycieli przekształconej spółki, prowadzi do postulowania ${ }^{27}$ liberalizacji bezwzględnego charakteru prawnego przedmiotowego terminu zawitego, poprzez możliwość oceny nadużycia prawa podmiotowego w oparciu o art. $5 \mathrm{kc}$. lub dopuszczalność zastosowania przepisów o zawieszeniu lub przerwaniu biegu terminu ${ }^{28}$.

Zwolennicy zachowania bezwzględnego charakteru przedmiotowego terminu zawitego wskazują przede wszystkim na dwa czynniki. Po pierwsze, na wyjątkowy charakter przepisu, a w związku z tym brak możliwości interpretacji rozszerzającej i odejście od wykładni literalnej, poprzez zastosowanie wykładni celowościowej. Po drugie zaś, na wypaczenie intencji ustawodawcy, wyraźnie wprowadzającego obie kategorie terminów, poprzez ewentualne zastosowanie do terminów zawitych reżimu regulującego bieg przedawnienia ${ }^{29}$.

Autorzy niniejszego artykułu podzielają postulat o doprecyzowanie sformułowania zawartego w przepisie art. $574 \mathrm{w}$ ten sposób, że jest to termin na wniesienie powództwa $^{30}$. Taka redakcja powołanego przepisu pozwoliłaby na rozwiązanie kwestii dyskusyjnych i przyjęcie jednolitego stanowiska w doktrynie i orzecznictwie, a jednocześnie zapewniłaby wystarczającą ochronę wierzycielowi osobowej spółki przekształcanej.

Równie ciekawym, choć budzącym mniej kontrowersji, jest termin określony w art. $564 \S 1$ ksh. Przepis ten odnosi się do ogólnych regulacji związanych z wezwaniem wspólników do oświadczenia o uczestnictwie w spółce przekształconej i stanowi, że spółka wezwie wspólników do złożenia w terminie miesiąca od dnia powzięcia uchwały o przekształceniu spółki oświadczeń o uczestnictwie w spółce przekształconej. Przedmiotowa regulacja wiąże się zatem z trzema zasadniczymi kwestiami, a mianowicie: terminem wezwania wspólników do złożenia oświadczenia, terminem złożenia oświadczenia o uczestnictwie oraz czasem trwania terminu do złożenia oświadczenia o uczestnictwie w spółce przekształconej.

Odnosząc się do zagadnienia terminu wezwania wspólników do złożenia oświadczenia o uczestnictwie w spółce przekształconej, ksh. nie reguluje tej kwestii $\mathrm{w}$ trybie przedmiotowego przepisu. Doktryna zajmuje odmienne stanowiska w tej kwestii. Zwolennicy jednego z poglądó $w^{31}$ zakładają, że ze względu na fakt, iż ustawodawca obarcza ryzykiem złożenia oświadczenia wspólników lub akcjonariuszy

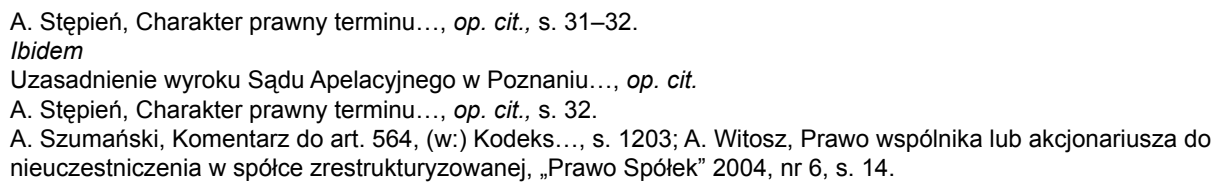


spółki, niewskazanie takiego terminu, może stanowić instrument do pozbywania się przez spółkę pewnych wspólników lub akcjonariuszy. W związku z powyższym oraz z zaledwie miesięcznym terminem na złożenie oświadczenia o przystąpieniu do spółki przekształconej, liczonym ponadto od dnia powzięcia uchwały, a nie od dnia zawiadomienia, spółka powinna wezwać do złożenia oświadczenia niezwłocznie po powzięciu uchwały o przekształceniu ${ }^{32}$. Bardziej radykalny pogląd, opierający się na literalnym brzmieniu przepisu, uznaje, że aby doszło do terminowego wykonania wszystkich czynności zawartych w przepisie, wspólnicy lub akcjonariusze spółki przekształcanej powinni zostać wezwani do złożenia oświadczenia o uczestnictwie przekształconej już w dniu podejmowania uchwały przekształceniowej ${ }^{33}$. W przeciwnym wypadku termin jednego miesiąca na złożenie oświadczenia będzie krótszy dla wspólników lub akcjonariuszy, którzy otrzymali takie zawiadomienie np. listem poleconym.

Miesięczny termin, określony w przepisie art. 564 - do złożenia oświadczenia o uczestnictwie w spółce przekształconej, jest pozasądowym terminem zawitym, zaś skutkiem jego upływu jest domniemanie ustawodawcy o nieuczestniczeniu wspólnika lub akcjonariusza w spółce przekształconej ${ }^{34}$. Bezskuteczny upływ terminu powoduje zatem, że wspólnik lub akcjonariusz traci swoje uprawnienie przystąpienia do spółki przekształconej, chyba że zaistnieją przesłanki stanowiące podstawę odmowy wpisu do rejestru spółki przekształconej ${ }^{35}$. Biorąc pod uwagę pewność obrotu prawnego i interesy wierzycieli, przedmiotowy termin zawity wyklucza dopuszczalność jego przedłużania mimo istnienia możliwości modyfikacji pozasądowych terminów zawitych. Jedyną dopuszczalną zmianą w tym przypadku jest zastosowanie przepisów o zawieszeniu biegu przedawnienia z powodu siły wyższej (art. 121 pkt 4 kc.) $)^{36}$.

Roszczeniem przysługującym wspólnikowi lub akcjonariuszowi z tytułu nieuczestniczenia w spółce przekształconej jest roszczenie o wypłatę ekwiwalentu pieniężnego wartości jego udziałów lub akcji, które posiadał w spółce przekształcanej na podstawie przepisu art. $565 \S 1 \mathrm{ksh}$. lub w sytuacji, gdy do przekroczenia jednomiesięcznego terminu doszło z winy spółki odpowiedzialność jej organów na podstawie przepisu art. $568 \S 1 \mathrm{ksh} .{ }^{37}$

M. Rodzynkiewicz, Kodeks spółek handlowych. Komentarz, Wyd. 3, Warszawa 2009, s. 1344.

A. Witosz, Komentarz do artykułu 564, (w:) Kodeks spółek handlowych. Komentarz, J. Frąckowiak, A. Kidyba, W. Popiołek, W. Pyzioł, A. Witosz, Warszawa 2008, s. 1280; B. Draniewicz, Oświadczenie o uczestnictwie w spółce przekształconej - wybrane zagadnienia praktyczne, „Prawo Spółek” 2005, nr 10, s. 13.

A. Witosz, Komentarz do artykułu 564, (w:) Kodeks..., op. cit., s. 1280.

A. Witosz, Charakter prawny prawa wspólnika lub akcjonariusza do nieuczestniczenia w spółce przekształconej, „Prawo Spółek” 2005, nr 4, s. 7.

M. Rodzynkiewicz, Kodeks..., op. cit., s. 1344. 
Ostatnia kwestią związaną terminem zawitym określonym w przepisie art. 564, jest czas trwania terminu do składania oświadczenia o uczestnictwie w spółce przekształconej. Część doktryny twierdzi, że termin ten jest zbyt krótki i niejasny dla wspólnika $^{38}$. Jak słusznie wskazuje jednak A. Szumański ${ }^{39}$, termin ten jest zgodny z naturą spółek handlowych, które są domeną ludzi aktywnych i dbających o swoje interesy, ponadto jego celem jest zagwarantowanie szybkiego zakończenia procesu przekształcenia ${ }^{40}$.

\section{Podsumowanie}

Element czasu i jego upływ odgrywają istotną rolę w prawie handlowym. Od precyzyjnego ujęcia elementu czasu jako terminu, także w kodeksie spółek handlowych, zależy bowiem reakcja - działanie lub zaniechanie podmiotów obrotu gospodarczego. Pomimo określenia cech charakterystycznych, pozwalających na zakwalifikowanie konkretnego terminu ksh do kategorii terminów przedawnienia lub zawitych, czynność ta nie jest prosta. Brak uregulowania lub precyzyjnego sformułowania terminu przez ustawodawcę wprowadza możliwość jego różnorodnej interpretacji. Prowadzi to do sytuacji, w której z powodu wielu dopuszczalnych rozumień tego samego przepisu, jego zastosowanie znajdzie odmienne rozwiązanie, nawet w podobnych stanach faktycznych. Nie wystarczy zatem stworzenie katalogu cech pozwalających na określenie charakteru prawnego danego terminu i wywodzenia w związku z tym określonych skutków. Należy dążyć do precyzyjnego ujęcia regulacji danej materii, zwłaszcza tak istotnego elementu, jakim jest upływ czasu, tak aby konkretne przepisy odnoszące się do poszczególnych instytucji tworzyły logiczną i spójną całość i nie pozostawiały wątpliwości co do sposobu interpretacji danego przepisu. 


\title{
THE LEGAL NATURE OF TERMS IN THE POLISH COMMERCIAL COMPANIES CODE
}

\author{
SUMMARY
}

Polish Commercial Companies Code (PCCC) uses a number of terms, understood in accordance with the provisions of civil law, both as a period of time and a moment. The aim of this paper is primarily a general description of the legal nature of two categories of terms - limitation period for claims and imperative terms included in the PCCC. Identification and discussion of these terms is related to the existing case law in the doctrine or the controversy associated with their vague wording.

This article consists of two components. The first points out the fundamental differences between limitation period for claims and imperative terms linked to their legal nature on the grounds of civil law. The second part is an analysis of selected examples of both periods. The summary is a postulate addressed to the legislature to consider changes in terms of selected terms of the law, to eliminate doubts. 